\title{
PENGARUH SUPERVISI KEPALA SEKOLAH DAN MOTIVASI KERJA GURU TERHADAP KEPUASAN KERJA GURU
}

\author{
WITRI OCTARY NANDA \\ witrioctary96@gmail.com
}

\begin{abstract}
ABSTRAK
Dalam penelitian ini, data yang diperoleh adalah berupa data hasil peristiwa yang sudah berlangsung berdasarkan pengukuran terhadap gejala yang ada. Teknik yang digunakan dalam pengumpulan data ini yaitu seperti angket dengan mengunakan skala likert dan linier. Penggunaan teknik dengan skala likert dan linier ini adalah untuk mengetahui pengaruh secara bersama-sama dan sendiri-sendiri dengan taraf signifikan 5\%.
\end{abstract}

Kata kunci: Supervisi kepala sekolah, motivasi kerja guru, kepuasan kerja guru.

\section{LATAR BELAKANG}

Kepala sekolah harus memenuhu standar kompetensi kepala sekolah sesuai dengan Peraturan Menteri Pendidikan Nasional No. 13/2007 tentang standar kepala sekolah atau madrasah. Peran kepala sekolah dan guru akan berjalan dengan baik apabila di dukung dengan melakukan supervisi terhadap kepala sekolah dan guru.

Selain supervisi, dukungan motivasi kerja guru yang tinggi juga dapat mempengaruhi kepuasan kerja guru dalam menjalakan tugas-tugasnya sebagai seorang pendidik yang baik. Jika seorang guru memiliki kepuasan kerja yang baik, maka gru tersebut cenderung akan menampakkan sikap yang positif sebagai seorang pendidik.

Upaya yang dilakukan untuk mengkondisikan guru untuk dapat melaksanakan tugasnya dengan baik, bisa dilakukan melalui pemberian penataran, pelatihan, supervisi, dan memberikan motivasi kerja yang baik terhadap guru. sabandi(Sabandi, 2013)

\section{PEMBAHASAN}

Penelitian dilakukan bertujuan untuk mengetahui bagaimana pengaruh supervisi kepala sekolah terhadap kepuasan kerja guru. Mengetahui bagaimana pengaruh motivasi kerja guru terhadap kepuasan kerja guru. Mengetahui pengaruh supervisi kepala sekolah dan maotivasi kerja secara bersama-sama terhadap kepuasan kerja guru.Rifaldi(Rifaldi, 2014)

1. Pengaruh Supervisi Kepala Sekolah Terhadap Kepuasan Kerja Guru

Menurut hasil penelitian yang telah dilakukan yaitu supervisi kepala sekolah berpengaruh positif dan signifkikan terhadap kepuasan kerja guru. Jika kegiatan supervisi yang dilakukan oleh kepala sekolah dapat meningkatkan kepuasan kerja guru.

Jadi, dapat disimpulkan bahwa pengaruh supervisi kepala sekolah terhadap kepuasan kerja guru menunjukkan bahwa apabila supervisi kepala sekolah 
dilaksanakan memberikan kontribusi nyata terhadap peningkayan kepuasan kerja guru.

\section{Pengaruh Motivasi Kerja Guru Terhadap Kepuasan Kerja Guru}

Berdasarkan hasil penelitian ini diperoleh bahwa motivasi kerja guru berpengaruh secara positif dan signifiakan terhadap kepuasan kerja guru. Jika motivasi guru dapat dilaksanakan dengan baik maka dapat meningkatkan kepuasan kerja guru.

Jadi, dapat disimpulkan bahwa pengaruh motivasi guru terhadap kepuasan kerja guru menunjukkan apabila motivasi kerja guru tinggi, akan memberikan kontribusu nyata terhadap peningkatan kepuasan kerja guru.

3. Pengaruh Supervisi Kepala Sekolah dan Motivasi Kerja Guru Terhadap Kepuasan Kerja Guru

Dalam penelitian yang dilakukan secara bersama-sama antara supervisi kepala sekolah dengan motivasi kerja guru berpengaruh terhadap kepuasan kerja guru. Jadi dapat dikatakan supervisi kepala sekolah dan motivasi kerja guru berpengaruh secara positif dan signifikan terhadap kepuasan kerja guru. Maksudnya yaitu, apabila supervisi kepala sekolah dan motivasi kerja guru dapat dilaksanakan secara bersama-sama maka dapat meningkatkan kepuasan kerja guru.

Jadi dapat disimpulkan bahwa pengaruh supervisi kepala sekolah dan motivasi kerja guru bersama-sama terhadap kepuasan kerja guru menunjukkan bahwa apabila supervisi kepala sekolah dan motivasi kerja guru dilaksanakan akan memberikan kontribusi nyata terhadap peningkatan kepuasan kerja guru.

\section{KESIMPULAN}

Dari hasil penelitian yang dilakukan dapat disimpulkan:

a. Supervisi yang dilakukan oleh kepala sekolah berpengaruh positif terhadap kepuasan kerja seorang guru .

b. Motivasi kerja guru berpengaruh positif terhadap kepuasan kerja guru sebagai seorang pendidik.

c. Supervisi kepala sekolah dan motivasi kerja guru secara bersama-sama berpengaruh secara positif terhadap kepuasan kerja guru. 


\section{REFERENSI}

Rifaldi, muhammad ali. (2014). Pengaruh Supervisi Kepala Sekolah Dan Motivasi Kerja Guru Terhadap Kepuasan Kerja Guru. Ijurnal Inspirasi Manajemen Pendidikan, IV(4), 122-133.

Sabandi, A. (2013). Supervisi Pendidikan Untuk Pengembangan Profesionalitas Guru Berkelanjutan. Pedagogi, Jurnal Ilmiah Ilmu Pendidikan, XIII(2), 1-9. Retrieved from http://ejournal.unp.ac.id/index.php/pedagogi/article/view/4275 